\title{
RELATIONSHIP BETWEEN AIRBORNE MICROBIAL AND PARTICULATE MATTER CONCENTRATIONS IN THE AMBIENT AIR AT A MEDITERRANEAN SITE
}

\author{
L. RAISI ${ }^{1}$ \\ M. LAZARIDIS ${ }^{2}$ \\ E. KATSIVELA ${ }^{1, *}$
}

${ }^{1}$ Department of Natural Resources and Environment,
Technological Educational Institute of Crete,
Romanou 3, 73133 Chania, Crete, Creece
${ }^{2}$ Department of Environmental Engineering,
Technical University of Crete,
Polytechneioupolis, 73100 Chania, Crete, Greece

*to whom all correspondence should be addressed: e-mail: katsivela@chania.teicrete.gr

\begin{abstract}
The relationship between the viable airborne bacterial and fungal concentrations and the respirable particulate matter with aerodynamic diameter less than $10 \mu \mathrm{m}\left(\mathrm{PM}_{10}\right), 2.5 \mu \mathrm{m}$ $\left(\mathrm{PM}_{2.5}\right)$, and $1 \mu \mathrm{m}\left(\mathrm{PM}_{1}\right)$ in the ambient air was studied. An Andersen six stage viable particle sampler and a MAS 100 sampler were used for microbial measurements. Duplicates of samples were collected at each sampling period (20 campaigns in total) at a residential site in the city of Chania (Crete, Greece) during April, May and June 2008.

Mean concentration of the total sum of the six size fractions was $79 \pm 41 \mathrm{CFU} \mathrm{m}^{-3}$ for mesophilic heterotrophic bacteria, whereas for mesophilic fungi it was five times higher $(395 \pm$ $338 \mathrm{CFU} \mathrm{\textrm {m } ^ { - 3 }}$ ). Particulate matter measurements at the same time period at the same site revealed that the mean concentrations of $\mathrm{PM}_{10}, \mathrm{PM}_{2.5}$, and $\mathrm{PM}_{1}$ were $46 \pm 14,35 \pm 14$, and 28 $\pm 12 \mu \mathrm{g} \mathrm{m}^{-3}$, respectively, whereas the mean cumulate counts of $\mathrm{PM}_{1}$ particles was $5,059 \pm$ $\overline{1}, 973$ particles $\mathrm{cm}^{-3}$. The mean arithmetic concentration of the size distribution of the airborne fungi had a maximum at aerodynamic diameters between 2.1 and $3.3 \mu \mathrm{m}$. However, a maximum was not observed for the mean arithmetic concentration of the size distribution of the airborne heterotrophic bacteria. It was also observed that concentrations of airborne bacteria and fungi outdoors were highly variable and do not correlate with the particle number $\left(\mathrm{PM}_{1}\right)$ or mass concentration of $\mathrm{PM}_{10}, \mathrm{PM}_{2.5}$ and $\mathrm{PM}_{1}$. Thereby, the $\mathrm{R}^{2}$-values in all correlations were less than 0.3. However, the concentrations of airborne bacteria and fungi were decreased with increasing mass concentrations of $\mathrm{PM}_{10}, \mathrm{PM}_{2.5}$, or $\mathrm{PM}_{1}$ while were increased with increasing number concentration of $\mathrm{PM}_{1}$. In addition, the concentrations of airborne bacteria were increased with increasing concentrations of airborne fungi. Finally, the microbial or the particulate matter data did not correlate with meteorological parameters, such as temperature, relative humidity, wind speed and UV radiation in ambient conditions.
\end{abstract}

KEYWORDS: viable airborne bacteria and fungi, particulate matter, ambient air quality.

\section{INTRODUCTION}

Airborne particles are present throughout the environment. They originate in many different forms and affect visibility, climate, human health and the quality of life (Ruzer and Harley, 2005). Once particles are in the atmosphere, transformation, transport and removal can take place. These processes depend on several factors, such as aerosol sizes, concentration and chemical composition, location and meteorological effects (ESPERE, 2009).

Above land surfaces almost a $25 \%$ of the total airborne particulate matter may be made up of biological materials (Jones \& Harrison, 2004). Biological material is present in the atmosphere 
in the forms of pollens, fungal spores, bacteria, viruses, any fragments from plants, animals or any living organism. The various types of material that occur in the biological aerosol (bioaerosol) have size range which varies from 0.02 up to $100 \mu \mathrm{m}$ (Macher et al, 1998). Pollens from anemophilous plants have typical diameters of 17 - $58 \mu \mathrm{m}$ (Stanley \& Linskins, 1974), fungal spores are typically 1-30 $\mu \mathrm{m}$ in diameter (Gregory, 1973), bacteria are typically $0.25-8 \mu \mathrm{m}$ in diameter (Thompson,1981), while viruses have diameter which are typically less than $0.3 \mu \mathrm{m}$ (Taylor, 1988).

Considering the importance of their potential implications for human health, agricultural productivity, and ecosystem stability, surprisingly little is known regarding the composition or dynamics of the atmosphere's microbial inhabitants. Most of the published studies focused on the study of bioaerosols of the indoor (Parat et al., 1999) or outdoor air originated from specific emission sources (Stelzenbach, 2007), such as waste water treatment plants (Ranalli et al., 2000, Pascual et al., 2003, Karra \& Katsivela, 2007) and Sahara dust events (Polymenakou et al., 2008). Even less is known about the natural microbial community in the urban areas (Brodie et al., 2007) and their relationship to the particulate matter in ambient air (Boreson et al., 2004).

Airborne microbial quantity and quality vary with time of day, year and location (Lighthart, 2000). The microbial flux and therefore the quantity in the air are thought to be associated with solar heating processes that somehow cause the release and affect the survival of bacteria and fungi into the atmosphere (Lighthart, 2000; Karra \& Katsivela, 2007). Phylogenetic analyses revealed that the atmospheric microbial community structure depends on particle size (Polymenakou et al, 2008).

The primary aim of the present study was to examine the size distribution of viable aerosolized microbes. Variations in the culturable heterothophic bacteria and fungi are discussed in terms of (a) their diurnal late morning-midday variation during April, May and June 2008 in a suburban, residential site which is located at the coastal Mediterranean city of Chania (Crete, Greece), (b) their correlation to the respirable $\mathrm{PM}_{1}, \mathrm{PM}_{2.5}$ and $\mathrm{PM}_{10}$ particle concentrations, and (c) the effect of meteorological conditions to the ambient air concentrations of microbes and particles. This is the first study to our knowledge, which investigates the arithmetic size distribution concentration of viable airborne microorganisms in conjunction to respirable PM and ambient meteorological conditions at the Mediterranean area during springearly summer where the ambient temperature is higher than $20{ }^{\circ} \mathrm{C}\left(20-26.5^{\circ} \mathrm{C}\right)$, the relative humidity varies from 33 to $64 \%$, and the UV radiation from 450 to $920 \mathrm{~W} \mathrm{~m}^{-2}$.

\section{MATERIALS AND METHODS}

An Andersen six stage viable particle sampler (Thermo Electron Corporation, USA) and a MAS 100 one stage sampler (Merck, Germany) were used for viable microbial measurements in the ambient air. The mass size distribution of particle collection by an Andersen six stage viable particle sampler with flow rate of $25 \mathrm{~mL} \mathrm{~min}{ }^{-1}$ was as follows: stage 1: particles larger than $7 \mu \mathrm{m}$; stage 2: between 4.7 - $7 \mu \mathrm{m}$; stage 3: between 3.3 $-4.7 \mu \mathrm{m}$; stage 4: between 2.1 $-3.3 \mu \mathrm{m}$; stage 5: between $1.1-2.1 \mu \mathrm{m}$; and stage 6: between $0.65-1.1 \mu \mathrm{m}$. The collected air volume was $500 \mathrm{~L}$. In parallel, the MAS 100 one stage sampler was used to collect viable particles larger than $1.1 \mu \mathrm{m}$ with a flow rate of $100 \mathrm{~L} \mathrm{~min}^{-1}$ and coincides with the level 5 of the Andersen sampler. The collected air volume by the MAS 100 sampler varied from $100 \mathrm{~L}$ to $250 \mathrm{~L}$. The mesophilic heterotrophic bacteria were cultivated in Tryptone Soy Agar (Merck, Germany) at $37{ }^{\circ} \mathrm{C}$ for $48 \mathrm{~h}$. Incubation temperature of $37{ }^{\circ} \mathrm{C}$ was chosen for the determination of the heterochthonous (not indigenous) heterotrophic bacteria. In parallel, fungi were cultivated in Malt Extract Agar (Lab M, England) at $20^{\circ} \mathrm{C}$ for $72 \mathrm{~h}$. Concentrations of airborne microorganisms were expressed as colony forming units per cubic meter $\left(\mathrm{CFU} \mathrm{\textrm {m } ^ { - 3 }}\right)$.

A portable aerosol particulate monitor (Dust-Trak instrument, TSI, Germany) measured the concentrations of particulate matter with aerodynamic diameter less than $10 \mu \mathrm{m}\left(\mathrm{PM}_{10}\right), 2.5$ $\mu \mathrm{m}\left(\mathrm{PM}_{2.5}\right)$, and $1 \mu \mathrm{m}\left(\mathrm{PM}_{1}\right)$ in the ambient air, while a portable ultra fine particle counter (PTrak instrument, TSI, Germany) measured the cumulative counts of $\mathrm{PM}_{1}$ particles. Mass concentrations per cubic meter were expressed as $\mathrm{g} \mathrm{m} \mathrm{m}^{-3}$, while cumulative counts per air volume as particles per cubic centimeter $\left(\mathrm{pt} \mathrm{cm}^{-3}\right)$. Meteorological variables (temperature, 
relative humidity and wind speed) were determined by a portable air velocity meter (VelociCalc instrument, TSI, Germany) simultaneously. In addition, the UV radiation and the mean daily wind speed were recorded from the Meteorological Station at Akrotiri station (Chania) (Meteorological Network of the National Observatory of Athens, http://penteli.meteo.gr/stations/chania/).

Duplicates of samples were collected at each sampling period (20 campaigns in total at 20 different days). The sampling time period was from 10 a.m. to 2 p.m. All instruments were positioned at a height of $0.765 \mathrm{~m}$ from the ground at a paved courtyard. The sampling site was at the suburban Halepa, a residential area of the city of Chania, a town of 60,000 people (Crete, Greece). The sampling site is located $2 \mathrm{~km}$ away from the city center and approximately $500 \mathrm{~m}$ from the sea.

\section{RESULTS AND DISCUSSION}

It was observed that the concentrations of viable airborne bacteria and fungi in the ambient air were highly variable during the measurement period (Figure 1). In addition, in the Table 1 are summarized the mean concentrations of the different size fractions of the viable, airborne heterotrophic bacteria and fungi.

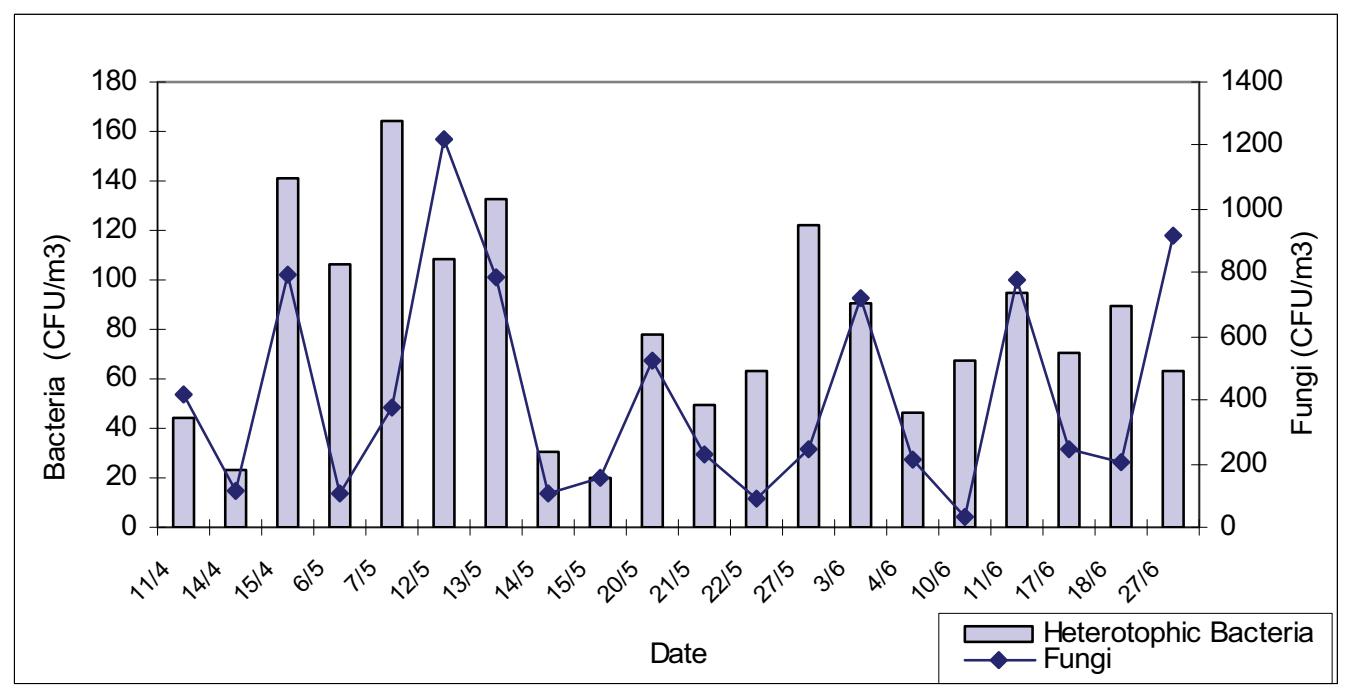

Figure 1. Mean concentrations of the sum of the 6 size fractions of viable airborne heterotrophic bacteria and fungi in the ambient air during measurements at different days in the time interval from April to June 2008

Table 1. Mean concentrations of viable, airborne heterotrophic bacteria and fungi in the ambient air during April-June 2008

\begin{tabular}{|c|c|c|c|c|c|c|}
\hline \multirow[b]{2}{*}{$\begin{array}{c}\text { Aerodynamic } \\
\text { diameter }\end{array}$} & \multicolumn{2}{|c|}{ April } & \multicolumn{2}{|c|}{ May } & \multicolumn{2}{|c|}{ June } \\
\hline & $\begin{array}{l}\text { Heterotrophic } \\
\text { Bacteria } \\
(\text { CFU m } \\
\text {-3) }\end{array}$ & $\begin{array}{c}\text { Fungi } \\
\left.\text { (CFU m }{ }^{-3}\right)\end{array}$ & $\begin{array}{l}\text { Heterotrophic } \\
\text { Bacteria } \\
(\text { CFU m-3) }\end{array}$ & $\begin{array}{c}\text { Fungi } \\
(\text { CFU m } \\
\text {-3 })\end{array}$ & $\begin{array}{l}\text { Heterotrophic } \\
\text { Bacteria } \\
\left(\text { CFU m }{ }^{-3}\right)\end{array}$ & $\begin{array}{c}\text { Fungi } \\
(\text { CFU m } \\
\text {-3) }\end{array}$ \\
\hline$>7 \mu \mathrm{m}$ & 22 & 49 & 16 & 33 & 15 & 34 \\
\hline $4,7-7 \mu \mathrm{m}$ & 12 & 35 & 12 & 33 & 11 & 48 \\
\hline $3,3-4,7 \mu \mathrm{m}$ & 10 & 103 & 16 & 102 & 9 & 148 \\
\hline $2,1-3,3 \mu \mathrm{m}$ & 10 & 167 & 14 & 170 & 15 & 170 \\
\hline $1,1-2,1 \mu \mathrm{m}$ & 8 & 75 & 23 & 44 & 20 & 42 \\
\hline $0,65-1,1 \mu \mathrm{m}$ & 7 & 13 & 7 & 3 & 5 & 3 \\
\hline $\begin{array}{c}\text { SUM of } 6 \\
\text { stages }\end{array}$ & 69 & 443 & 88 & 384 & 75 & 445 \\
\hline MAS 100 & 92 & 353 & 101 & 515 & 142 & 578 \\
\hline
\end{tabular}


As shown in Table 1, airborne fungi present significant higher concentrations than airborne heterotrophic bacteria, whereas the highest concentrations were measured in June 2008. The temperature varied from 24 to $36.5^{\circ} \mathrm{C}$, while the relative humidity varied from 33 to $60 \%$, the wind speed during sampling from 0.4 to $1.7 \mathrm{~m} \mathrm{~s}^{-1}$, the mean daily wind speed from 3.5 to 8.2 $\mathrm{m} \mathrm{s}^{-1}$ and the UV radiation from 660 to $914.5 \mathrm{~W} \mathrm{~m}^{-2}$ during June 2008. The arithmetic mean concentration and its corresponding standard deviation of all measurements from April to June of the total sum of the six size fractions was $79 \pm 41$ CFU $\mathrm{m}^{-3}$ for mesophilic heterotrophic bacteria, whereas for fungi was $395 \pm 338$ CFU $\mathrm{m}^{-3}$. In comparison, data generated from the MAS 100 one stage sampler were higher than those from the Andersen sampler.

Similarly to the airborne microbial data, the mean concentrations of the respirable PM fractions $\mathrm{PM}_{1}, \mathrm{PM}_{2.5}$ and $\mathrm{PM}_{10}$, presented in Figure 2, showed high diurnal late morningmidday variability in the ambient air. The arithmetic mean concentrations of the $\mathrm{PM}_{1}, \mathrm{PM}_{2.5}$ and $\mathrm{PM}_{10}$ particles, and the meteorological parameters in the ambient air in the period from April to June 2008 are summarized in Table 2.

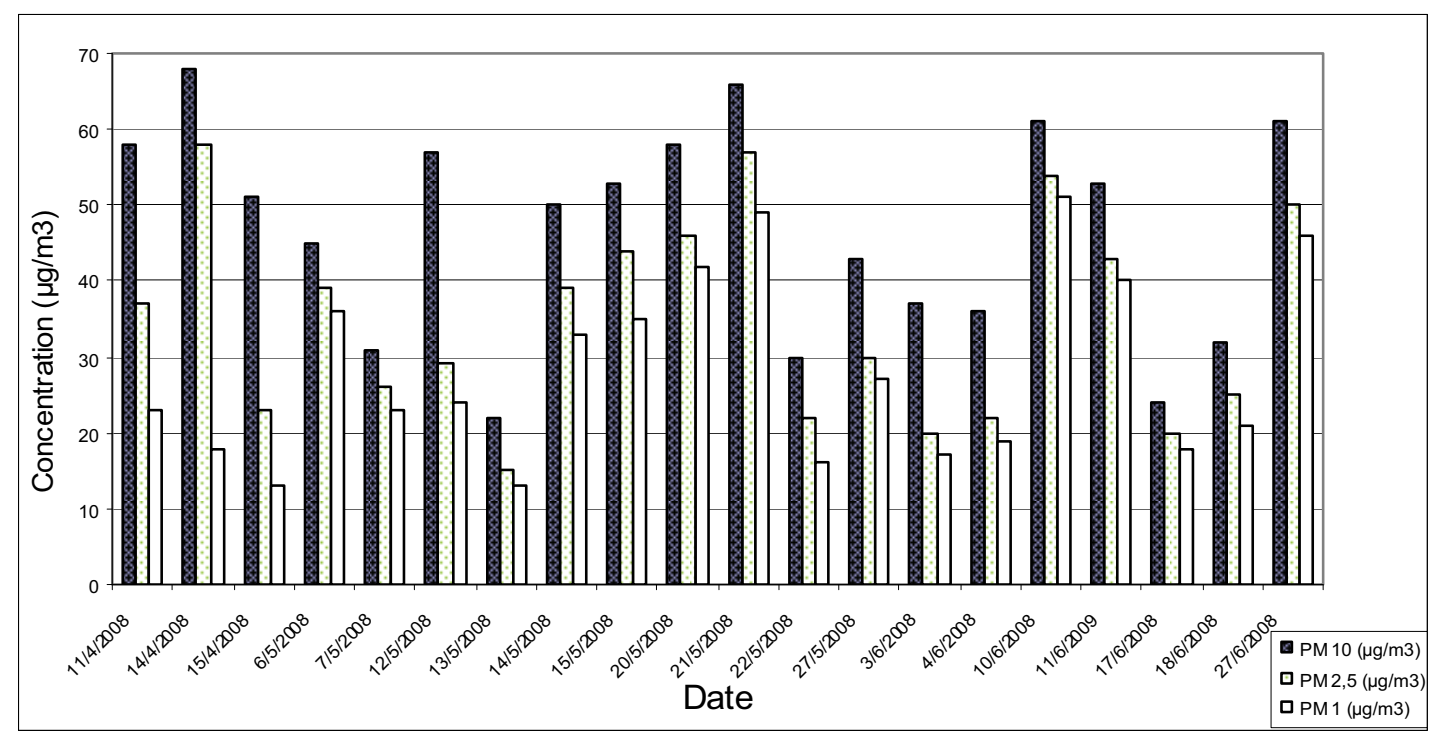

Figure 2. Mean mass concentrations of $\mathrm{PM}_{1}, \mathrm{PM}_{2.5}$ and $\mathrm{PM}_{10}$ particles in the ambient air during measurements at different days during April, May, and June 2008

Table 2. Mean concentrations of $\mathrm{PM}_{1}, \mathrm{PM}_{2.5}$ and $\mathrm{PM}_{10}$ particles, and mean values of meteorological parameters in the ambient air during April-June 2008

\begin{tabular}{cccc}
\hline Parameter & April & May & June \\
\hline $\mathrm{PM}_{10}\left(\mu \mathrm{g} \mathrm{m}^{-3}\right)$ & 59 & 46 & 43 \\
\hline $\mathrm{PM}_{2.5}\left(\mu \mathrm{g} \mathrm{m}^{-3}\right)$ & 39 & 35 & 33 \\
\hline $\mathrm{PM}_{1}\left(\mu \mathrm{g} \mathrm{m}^{-3}\right)$ & 18 & 30 & 30 \\
\hline $\mathrm{PM}_{1}\left(\mathrm{pt} \mathrm{cm}^{-3}\right)$ & 4,72 & 5,08 & 4,99 \\
\hline $\mathrm{T}\left({ }^{\circ} \mathrm{C}\right)$ & 21.9 & 22.8 & 28.2 \\
\hline $\mathrm{RH}(\%)$ & 56.23 & 55.16 & 48.72 \\
\hline $\mathrm{U}_{\text {during sampling }}\left(\mathrm{m} \mathrm{s}^{-1}\right)$ & 0.82 & 0.49 & 1.05 \\
\hline $\mathrm{U}_{\text {daily }}\left(\mathrm{m} \mathrm{s}^{-1}\right)$ & 11.7 & 8.72 & 5.9 \\
\hline $\mathrm{UV}$ radiation $\left(\mathrm{W} \mathrm{m}^{-2}\right)$ & 683.1 & 748.2 & 839.4 \\
\hline
\end{tabular}

At the total sampling period (April to June 2008) of this study, the mean concentrations and their corresponding standard deviation of $\mathrm{PM}_{10}, \mathrm{PM}_{2.5}$, and $\mathrm{PM}_{1}$ were $46 \pm 14,35 \pm 14$, and 28 $\pm 12 \mu \mathrm{g} \mathrm{m}^{-3}$, respectively, whereas the mean cumulate counts of $\mathrm{PM}_{1}$ particles was $5,059 \pm$ 1,973 particles $\mathrm{cm}^{-3}$. The $\mathrm{PM}_{10}$ mass concentration was measured many times to exceed the legislative daily upper limit of $50 \mu \mathrm{g} \mathrm{m}^{-3}$ (Figure 2). It was observed that concentrations of 
$\mathrm{PM}_{10}$ correlate well with $\mathrm{PM}_{2.5}\left(\mathrm{R}^{2}\right.$-value of 0.77$)$, while low correlation with the mass concentration of $\mathrm{PM}_{1}\left(\mathrm{R}^{2}\right.$-value of 0.39$)$ was observed. The variation of the mean mass concentrations of $\mathrm{PM}_{1}, \mathrm{PM}_{2.5}$ and $\mathrm{PM}_{10}$ particles during the whole sampling period can be observed in the Figure 2.

The arithmetic size distribution concentration of biological loading in different PM fractions varies with the studied parameter. The mean concentration size distribution of the six different fractions of the airborne fungi had a maximum at aerodynamic diameters between 2.1 and 3.3 $\mu \mathrm{m}$ (Figure 3). In contrast, an equal distribution without any maximum was observed for the mean concentration size distribution of the six different fractions of the airborne heterotrophic bacteria. Besides the microbial data presented in this study, an increase of biological loading (in terms of protein loading) was measured with higher coarse PM concentrations in agreement with Boreson et al., (2004).

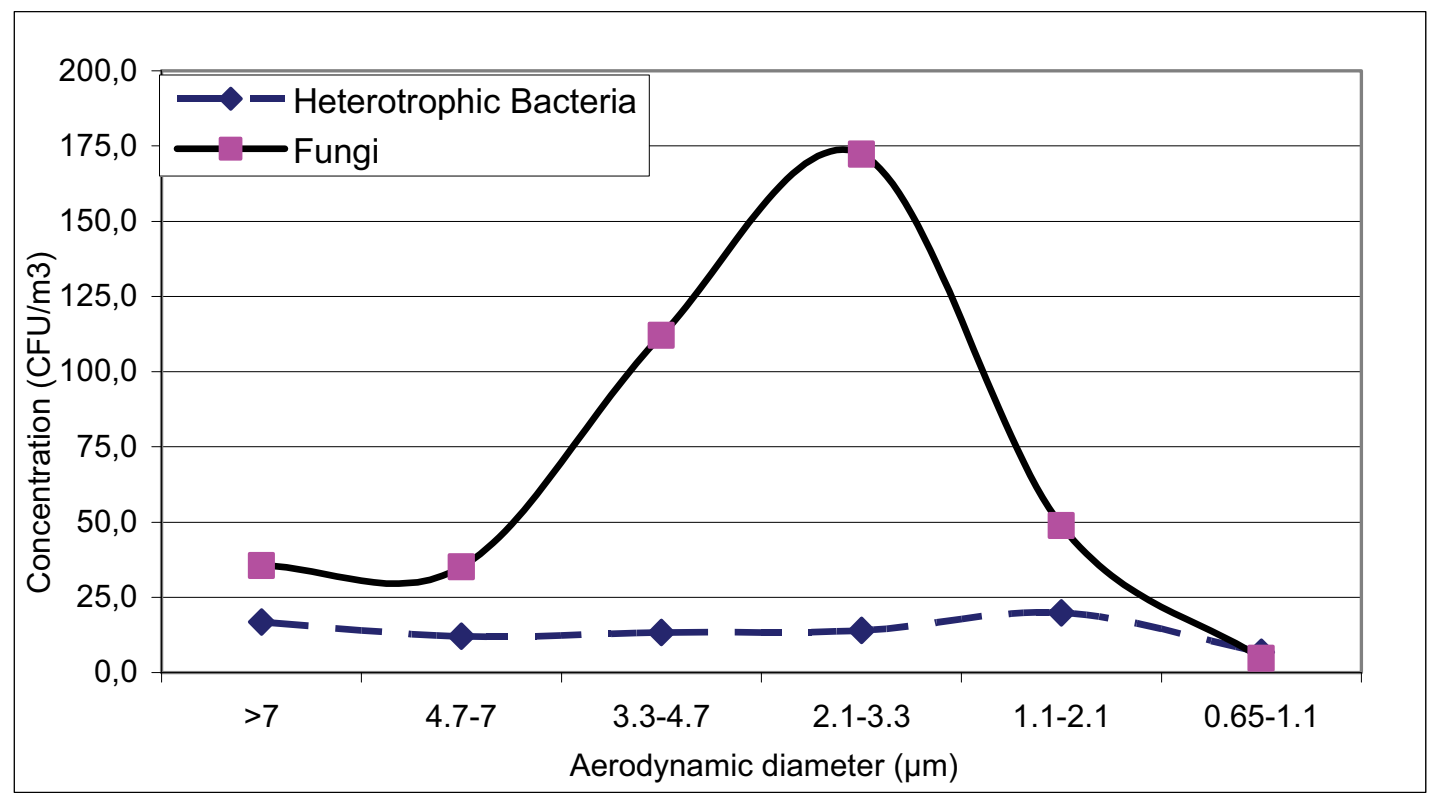

Figure 3. Mean concentrations size distribution of viable airborne heterotrophic bacteria and fungi in the ambient air during April, May, and June 2008

The concentration of each single fraction and of the sum of the 6 size fractions of the airborne viable heterotrophic bacteria and fungi was tested against the concentration of each PM fraction as well as against each of the measured environmental conditions ( $T, R H, U_{\text {during }}$ sampling, $U_{\text {dialy }}$, UV radiation) to determine possible correlations. The statistical analysis of the concentrations of airborne bacteria and fungi in the ambient air did not show any significant correlation with $\mathrm{PM}_{1}$ particle number or mass concentration of $\mathrm{PM}_{10}, \mathrm{PM}_{2.5}$ and $\mathrm{PM}_{1}$. Thereby, the $R^{2}$-values of all possible correlations were less than 0.3 in the ambient air conditions. Similar results were described also by Boreson et al., (2004) in ambient conditions.

However, consistent trends were resulted from the statistical analysis. The concentrations of airborne bacteria and fungi were decreased with increasing mass concentrations of $\mathrm{PM}_{10}$, $\mathrm{PM}_{2.5}$, or $\mathrm{PM}_{1}$. This negative correlation effect has been verified also using molecular based detection methods for airborne bacterial populations in urban aerosols originated from two cities in Texas, U.S.A. (Brodie et al., 2007). In contrast, the concentrations of airborne fungi with aerodynamic diameters between 2.1 and $3.3 \mu \mathrm{m}$ (which is the largest airborne fungi fraction as depicted in Figure 3 ) were increased with increasing number concentration of $\mathrm{PM}_{1}$ (positive correlation with $\mathrm{R}^{2}$-value 0.378 ) (Figure 4). In parallel, most of the time, high concentrations of airborne bacteria were associated with high concentrations of airborne fungi, as shown in Figure 1 . Thereby, the best linear positive correlation with a $R^{2}$-value of 0.357 was revealed among the concentrations of airborne microorganisms with aerodynamic diameters larger than $7 \mu \mathrm{m}$. 


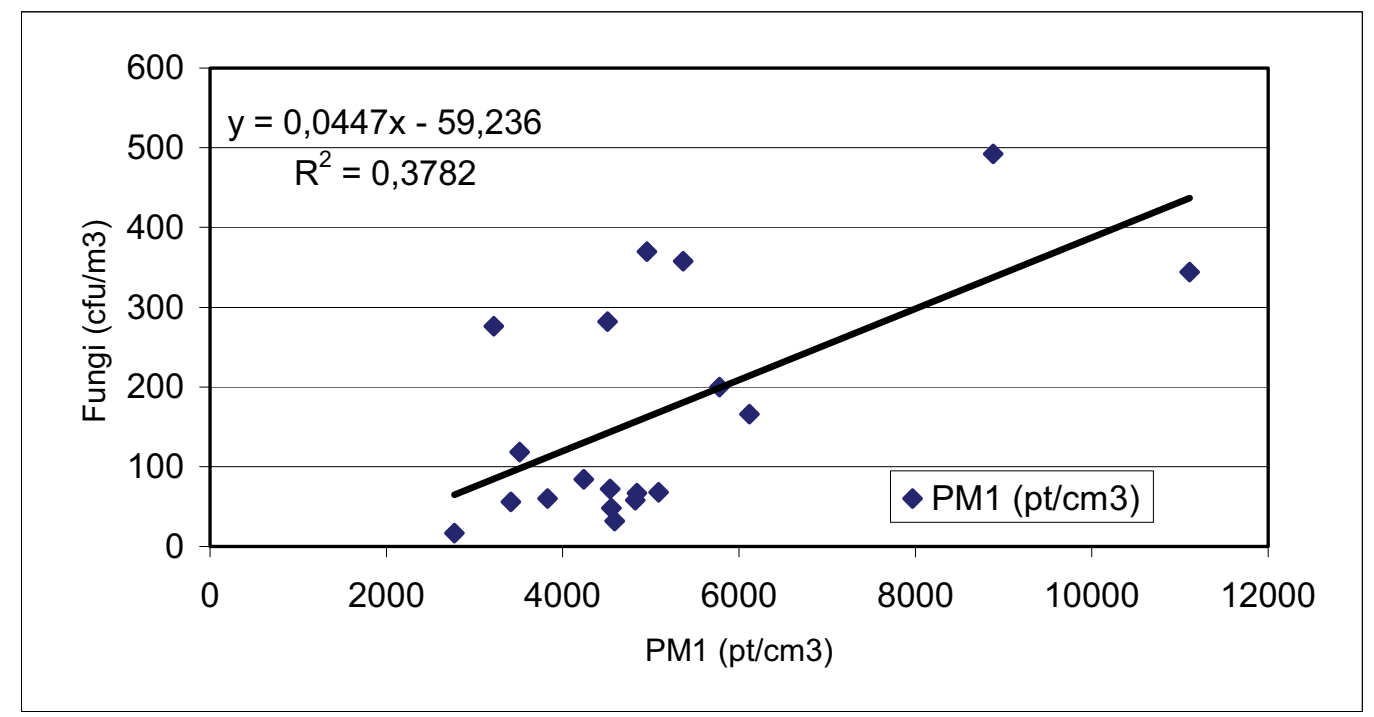

Figure 4. Linear relationship between viable airborne fungi with aerodynamic diameter from 2.1 to $3.3 \mu \mathrm{m}$ and the number concentration of $\mathrm{PM}_{1}$

In addition, the microbial (bacterial or fungal) or the particulate matter data did not have any significant linear relationship with ambient meteorological parameters, such as temperature, relative humidity, wind speed (during sampling or mean daily data), and UV radiation. The $\mathrm{R}^{2}$ values of all possible correlations (even from every single size fraction) were less than 0.25 . In our study, the relative humidity was observed to be the parameter with the highest correlation to the airborne microbial concentrations $\left(R^{2}\right.$-values 0.20 for bacteria and 0.25 for fungi). Thereby, it was observed that microbial concentrations were decreased by increasing relative humidity from 33 to $64 \%$. The relative humidity or the relative water content of the air has been shown also by many authors to be of major importance in the survival of airborne microorganisms (Maier et al., 2000).

The gradual increase of the mean ambient UV radiation from April to June 2008 (Table 2) did not show any negative effect on the microbial survival. This result is in accordance to published data of Peccia et al., (2001) that variations in UV spherical irradiance were minor and not statistically significant in the $20-95 \%$ relative humidity range in relation to the microbial ambient concentration. In our study, the gradual increase of the mean ambient temperature in conjunction with the slight decrease of the mean relative humidity seems to have a positive effect on the airborne microbial concentrations during spring and early summer (Tables $1 \& 2$ ). In contrast, measurements of airborne microorganisms operated by our group during summer time (July) at the same Mediterranean site concluded that the intensive solar radiation, together with further elevated ambient temperatures $\left(25-31{ }^{\circ} \mathrm{C}\right)$ is thought to be the most important factors for the low numbers of microbes in the air, also in relation to the emissions of a proper operated wastewater treatment plant (Karra \& Katsivela, 2007).

Brodie et al. (2007) demonstrated by a comprehensive molecular analysis of airborne bacteria, that urban aerosols contained at least 1,800 diverse bacterial types, a diverse assemblage of microorganisms representing the amalgamation of numerous point sources. Recently, Polymenakou et al., (2008) observed diverse bacterial phylotypes commonly found in soil and marine ecosystems, as well as on human skin in airborne particles of different sizes using also molecular based methods during an intense African dust event at the Eastern Mediterranean. In our study, the low correlation between microbial or PM data and the meteorological ambient parameters suggests that their origin may be related only to a low percentage to local dust resuspension. The results of this study show the necessity of a multivariant analysis of the measured parameters including also additional uncharacterized parameters (such as existence of nutrients, carbon sources, and vegetation, animal and human activities, long range air transport) in this investigation. 


\section{CONCLUSIONS}

Seasonal allergies and microbial mediated respiratory diseases can coincide with elevated bioaerosol concentrations. In addition, health responses may be enhanced when chemical and biological constituents of particulate matter are combined together. Because of these associations and also the health-related interests of monitoring different fractions of respirable $\mathrm{PM}\left(\mathrm{PM}_{1}, \mathrm{PM}_{2.5}\right.$ and $\left.\mathrm{PM}_{10}\right)$, the biological loading of viable airborne bacteria and fungi in 6 fractions of fine and coarse size ranges of PM was studied. Although, an equal distribution of the mean concentrations of the airborne heterotrophic bacteria was observed in the six different size fractions, the highest concentrations of the airborne fungi were determined at aerodynamic diameters between 2.1 and $3.3 \mu \mathrm{m}$.

In general, the concentrations of bioaerosols in the form of culturable (viable), airborne, heterochthonous heterotrophic bacteria, and mesophilic fungi had low correlation with mass concentrations of $\mathrm{PM}_{1}, \mathrm{PM}_{2.5}$ and $\mathrm{PM}_{10}$ particles and cumulative counts of $\mathrm{PM}_{1}$ particles with $\mathrm{R}^{2}$-values less than 0.3 . The corresponding variability with the ambient temperature, relative humidity, wind speed and UV radiation was higher with $R^{2}$-values less than 0.2 . In the same time period, the mass concentrations of $\mathrm{PM}_{10}$ correlate with $\mathrm{PM}_{2.5}$ mass $\left(\mathrm{R}^{2}\right.$-value of 0.77$)$, while low correlation was observed with the $\mathrm{PM}_{1}$ mass concentration $\left(R^{2}\right.$-value of 0.39$)$.

Further, long-term studies on the particle size distribution of aerosolized microbes in the ambient air in conjunction with multivariant analysis will provide a valuable understanding in the field of aerobiology. Constant relationships, and hence strong correlations, may only occur under certain conditions, such as steady abiotic and biotic emission sources, and constant meteorological conditions.

\section{REFERENCES}

Boreson J., Dillner A.M., Peccia J. (2004), Correlating bioaerosol load with $\mathrm{PM}_{2.5}$ and $\mathrm{PM}_{10 \mathrm{cf}}$ concentrations: a comparison between natural desert and urban-fringe aerosols, Atmospheric Environment, 38, 6029-6041.

Brodie E.L., De-Santis T.Z., Moberg Parker J.P., Zubietta I.X., Piceno Y.M., Andersen G.L. (2007), Urban aerosols harbor diverse and dynamic bacterial populations, Proceedings of the National Academy of Sciences of the United States of America, 104, 299-304.

ESPERE Climate encyclopaedia - clouds and particles, URL: http://www.espere.net (accessed 20/03/2009).

Gregory P.H. (1973), The Microbiology of the Atmosphere, Leonard Hall.

Jones A.M., Harrison R.M. (2004), The effects of meteorological factors on atmospheric bioaerosol concentrations-a review, Science of the Total Environment, 326, 151-180.

Karra S., Katsivela E. (2007), Microorganisms in bioaerosol emissions from wastewater treatment plants during summer at a Mediterranean site, Water Research, 41, 1355-1365.

Lighthart B. (2000), Mini-review of the concentration variation found in the alfresco atmospheric bacterial populations, Aerobiologia, 16, 7-16.

Macher J., Ammann H.A., Burge H.A., Milton D.K., Morey P.R. (1998), Bioaerosols: Assessment and Control, American Conference of Governmental Industrial Hygienists, Cincinnati, $\mathrm{OH}$, Cincinnati, USA.

Pascual L., Perez-Luz S., Yanez A.M., Santamaria A., Gibert K., Salgot M., Apraiz D., Catalan V. (2003), Bioaerosol emission from wastewater treatment plants. Aerobiologia 19, 261-270.

Parat S., Perdrix A., Mann S., Baconnier P. (1999), Contribution of particle counting in assessment of exposure to airborne microorganisms, Atmospheric Environment, 33, 951-959.

Peccia J., Hernandez M. (2001) Photoreactivation in airborne Mycobacterium parafortuitum. Applied and Environmental Microbiology, 67, 4225-4232.

Polymenakou P.N., Mandalakis M., Stephanou E.G., Tselepides A. (2008), Particle Size Distribution of Airborne Microorganisms and Pathogens during an Intense African Dust Event in the Eastern Mediterranean, Environmental Health Perspectives, 116, 292-296.

Ranalli G., Principi P., Sorlini C. (2000), Bacterial aerosol emission from wastewater treatment plants: culture methods and biomolecular tools, Aerobiologia, 16, 39-46.

Ruzer L.S., Harley N.H. (2005) Aerosols Handbook: Measurement, Dosimetry, and Health Effects, CRC Press, Florida, USA. 
Stanley R.G., Linskins H.F. (1974) Pollen: biology, chemistry and management, Springer Verlag, Berlin, Germany.

Stelzenbach L.D. (2007), Introduction to aerobiology. In: Hurst, C.J., et al., (Eds.), Manual of Environmental Microbiology. ASM Press, Washington, DC, pp. 925-938.

Taylor E.J. editor (1988) Dorland's medical dictionary. W. B. Sauders Co, Philadelphia, USA.

Thompson W. A. R. editor (1981) Black's medical dictionary, 33 eds. Adam and Charles Black. 